\title{
"Use of methods of operational cost management in the planning and accounting organization at the enterprises in Ukraine"
}

\author{
Yuriy Pogorelov (D) https://orcid.org/0000-0002-1192-874X \\ R http://www.researcherid.com/rid/S-1265-2018 \\ Ganna Kozachenko iD https://orcid.org/0000-0002-8153-771X \\ AUTHORS \\ R http://www.researcherid.com/rid/H-6861-2018 \\ levgen Ovcharenko iD https://orcid.org/0000-0001-5267-5067 \\ R http://www.researcherid.com/rid/L-4222-2018 \\ Olena Illiashenko iD https://orcid.org/0000-0002-2472-6362 \\ R http://www.researcherid.com/rid//-7026-2018
}

Yuriy Pogorelov, Ganna Kozachenko, levgen Ovcharenko and Olena Illiashenko ARTICLE INFO (2018). Use of methods of operational cost management in the planning and accounting organization at the enterprises in Ukraine. Problems and Perspectives in Management, 16(3), 488-500. doi: 10.21511/ppm.16(3).2018.39

DOI http://dx.doi.org/10.21511/ppm.16(3).2018.39

RELEASED ON Wednesday, 26 September 2018

RECEIVED ON Tuesday, 28 November 2017

ACCEPTED ON Tuesday, 11 September 2018

\section{(cc) EY-NO}

LICENSE

This work is licensed under a Creative Commons Attribution-NonCommercial 4.0 International License

JOURNAL

"Problems and Perspectives in Management"

ISSN PRINT

$1727-7051$

ISSN ONLINE $1810-5467$

PUBLISHER

LLC "Consulting Publishing Company "Business Perspectives"

FOUNDER LLC "Consulting Publishing Company "Business Perspectives"

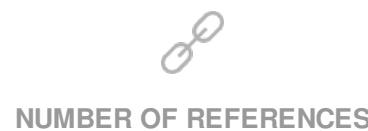

35
NUMBER OF FIGURES

0

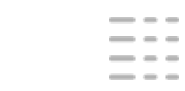

NUMBER OF TABLES

\section{7}

(C) The author(s) 2022. This publication is an open access article. 


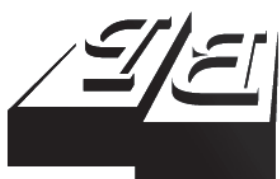

BUSINESS PERSPECTIVES

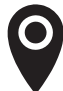

LLC "CPC "Business Perspectives" Hryhorii Skovoroda lane, 10, Sumy, 40022, Ukraine

www.businessperspectives.org

Received on: $28^{\text {th }}$ of November, 2017 Accepted on: $11^{\text {th }}$ of September, 2018

(C) Yuriy Pogorelov, Ganna Kozachenko, Ievgen Ovcharenko, Olena Illiashenko, 2018

Yuriy Pogorelov, Doctor of Economics, Associate Professor, Head of the Department of Accounting and Audit, Poltava National Technical Yuri Kondratyuk University, Ukraine.

Ganna Kozachenko, Doctor of Economics, Professor, Professor of the Department of Finance and Banking, Poltava National Technical Yuri Kondratyuk University, Ukraine.

Ievgen Ovcharenko, Doctor of Economics, Associate Professor, Head of the Department of Management and Marketing, Volodymyr Dahl East Ukrainian National University (Sievierodonetsk), Ukraine.

Olena Illiashenko, Doctor of Economics, Associate Professor Professor of the Department of Financial and Economic Security, Accounting and Audit, O. M. Beketov National University of Urban Economy in Kharkiv, Ukraine.

\section{(ㄷ)(1) (8)}

This is an Open Access article, distributed under the terms of the Creative Commons Attribution-NonCommercial 4.0 International license, which permits re-use, distribution, and reproduction, provided the materials aren't used for commercial purposes and the original work is properly cited.
Yuriy Pogorelov (Ukraine), Ganna Kozachenko (Ukraine),

Ievgen Ovcharenko (Ukraine), Olena Illiashenko (Ukraine)

\section{USE OF METHODS}

OF OPERATIONAL COST

MANAGEMENT IN THE PLANNING

AND ACCOUNTING

ORGANIZATION AT THE

ENTERPRISES IN UKRAINE

\begin{abstract}
The efficiency of the use of methods of operational cost management at the enterprise depends on the consistency of functional methods. As a matter of actual practice, cost management at Ukrainian enterprises lacks such consistency causing managerial collision due to inconsistency of planning and actual data on the enterprise costs. The objective of the article is to resolve the mentioned managerial collision. There has been presented a criterion of consistency of functional cost management methods (identity of data about planning and actual costs of the enterprise according to the format, structure of the resulting data and period of their receipt). The consistency of functional methods - making it possible to deal with the issue of information communications in the enterprise management - is provided by reducing the methods of cost management at the enterprise, in the form of operationalization of concepts of methods of operational cost management in functional methods. With the objective of ensuring the consistency of functional methods of cost management, the article determines changes in the cost accounting, making it possible to provide the consistency of planning and actual data on the enterprise costs and to analyze them.
\end{abstract}

\section{Keywords}

JEL Classification enterprise, costs, management, management method, concept, operationalization, consistency

\section{INTRODUCTION}

The enterprise costs are the object of management targeted at ensuring the consistency of their size and structure and the volume and conditions of production and marketing of products (performance of works or provision of services).

The enterprise costs management is made through joint implementation of a number of management functions, such as planning, accounting, analysis and control of costs being the basic ones. The consistency of planning and cost accounting of the enterprise is the fundamental for their analysis. At the same time, the results of cost control serve as the fundamental for coordination of the formation of their final amount and structure, the data on which are crucial for making managerial decisions on the production of outputs and enterprise marketing strategy.

In the modern economic science, there have been developed various methods for enterprise costs management, the use of which makes it 
possible to form the amount and structure of costs depending on several factors and according to the current (or expected) conditions of activity of the enterprise.

The efficiency of the use of cost management method is provided by the use of its concepts in planning and accounting of enterprise costs, making it possible to deal with managerial collision in cost management when requests and requirements for cost data for their planning and analysis are partly dissatisfying (or even fully) during the cost accounting function implementation. This managerial collision in cost management calls for resolution, as long as the enterprise accounting data serve as the main source of data on enterprise costs.

Thus, the provision of full usage of the concepts of enterprise costs management methods with any kind of activity in their planning and accounting is a major issue. Once resolved, it will help remove obstacles to the use of effective cost management methods, which, in its turn, will be good for the quality of such management thanks to a substantial improvement of its information communications.

Having analyzed modern scientific and educational materials on cost management, it is reasonable to suppose that the issue of consistent use of methods of operational cost management in planning and accounting of enterprise costs has not yet been addressed. The vast majority of sources take the essence of cost management methods by outlining the basic concepts of each of them. But the practical use of enterprise cost management methods through the operationalization of their concepts in functional cost management methods is not completely understood.

That is why we find it necessary to consider the ways of solving the issue of consistency of implementation of the cost management functions. First of all, it is necessary to consider costs planning and accounting by operationalization of the concepts of methods of operational cost management in functional methods. Also, it is important to determine - within the current regulations - amendments in cost accounting required to use current methods of cost management at the enterprise.

\section{THEORETICAL BASIS}

Production costs are a critical category of theoretical economics being studied for a long time. The reason for this is that the amount of costs is determinative for the amount of profit (however, in the case of perfect competition), it is also the source of expanded reproduction of capital of the enterprise and its growth. That is why today we have a serious theoretical basis made up of numerous theories and cost concepts whose principles are formed and tested in terms of practice for a long time. They are the fundamental for the enterprise cost management:

- the theory of labor value where the labor put into the product is the content of production costs (Smith, 2015; Ricardo, 1941; Marx, 2008);

- the costs and competition theory of Clark (1923) that introduced into economic science the concept of 'overhead costs' - costs that are not directly associated with the production process, but are the result of solid investments in fixed capital (Clark, 1923; Frank, 1990; Fiorito, 2018);

ubjective theory of the cost of alternative possibilities (Wieser, 1889), according to which the actual production costs of this product are equal to the highest value of those benefits that society would be able to obtain, if used these inputs in other way;

- the theory of transaction costs focuses on cooperation costs of a business entity (transaction costs) to plan and control its obligations in the course of alienation and granting of ownership (Coase, 1937; Commons, 1959; North \& Wallis, 1994; Williamson, 1981);

- marginal cost concept defines the costs the amount of which the company is able to control directly (this refers to both the costs of the company at the time of production of the last 
unit of production and the saved costs when reducing the production output to this last unit) (O'Sullivan \& Sheffrin, 2003; Backhouse, 2004; Backhouse, 2008).

The positions of these theories form an epistemological field of cost research, which is a system of knowledge on the nature of enterprise costs (resources productivity reflection), their types, direct connection with the production process and transfer of ownership, occurring in the course of interaction with the environment subjects, structural and functional relations between basic concepts due to the limited resources and possibilities of their alternative use, as well as a number of processes, procedures and methods to gain knowledge on the enterprise costs, principles of their formation and reimbursement.

The concentration of theoretical provisions on the content and behavior of the enterprise costs is relevant to the practice via a number of cost management methods representing the praxeological aspect of the scientific system of knowledge on the enterprise costs.

The method of enterprise cost management is a system of rules and practices of predetermination of the processes of formation of costs to attain their set amount and structure that operationalizes the main concepts of the idea of predetermination. Operationalization of concepts is a way of changing from the theoretical knowledge of costs to the practical one.

The methods of enterprise cost management are used to bring the value and the structure of costs, as well as their relations in line with other indicators of activity of the enterprise, according to the conditions of production and marketing of products (provision of services and performance of works). First of all, such a predetermination is focused on elimination (or substantial decrease) of the costs that are not associated with production, avoiding losses in the production and managerial activity of the enterprise due to poor organization of production, labor and management, as well as the negative impact of the environment.

A detailed description of the methods of enterprise cost management is given in the educational and scientific literature: there has been disclosed their nature and there were shown the focus of the methods, in particular according to the horizon of application (operational or strategic enterprise cost management), as well as the expected results of use. The results of the analysis of the methods of enterprise cost management (Drury, 1990; Drury, 2007; Horngren, 2008; Hansen, 2009; Imai, 1986; Elliott, 2014; Apak, Erol, Elagöz, \& Atmaca, 2012; Tichacek, 2006) made in Kozachenko (2007, pp. 43-61) enable to determine their advantages and limitations and outline the general conditions for their use (Tables 1 and 2).

However, practical enterprise cost management requires more than just knowledge of the nature of the methods. It is important to determine how the concepts of the chosen method are to be used in the implementation of cost management functions, first of all, in costs planning and accounting requiring further operationalization of management methods in functional cost management methods. This operationalization seeks both to determine specific actions, techniques, operations, and algorithms, the implementation of which is derived from the main idea of the method and to provide informational consistency of functional cost management methods, ensuring information communications in the enterprise cost management.

Against this background, the attention is focused on the methods of operational enterprise costs management. The strategic cost management methods (target - costing, LCC analysis, VCC method, costs benchmarking) are mainly used within strategic planning, that is why the issue of their consistent use while implementing cost management functions is no less important.

Modern scientific literature considers the solution of the issue of the full use of methods of operational enterprise cost management, thus ensuring information communication in cost management, mainly within the limits of managerial accounting (Upchurch, 1998; Sahaf, 2013; Horngren, 2008; Garg, 2004; Georgas, 1986; Wideman, 1983).

Management accounting makes it possible to detect, collect, format in a prescribed manner, and provide, within fixed period, planning and ac- 
Table 1. The nature and general conditions of the use of methods of operational enterprise cost management

\begin{tabular}{|c|c|c|}
\hline Method & Nature of the method & General conditions of the use of method \\
\hline Direct costing & $\begin{array}{l}\text { Fixed overhead costs that are not associated with } \\
\text { production and not included in the production prime } \\
\text { cost, but are directly related to the profit and loss } \\
\text { account during the period in which they arose. } \\
\text { The production prime cost is taken into account and } \\
\text { planned only in a part of variable costs. Fixed costs are } \\
\text { not included in the prime cost of products, but written } \\
\text { off from profits as the period costs during the period in } \\
\text { which they arose (Nikolaeva, 1993, p. 34) }\end{array}$ & $\begin{array}{l}\text { Mandatory division of costs into variable and fixed, } \\
\text { direct and overhead. } \\
\text { Determination of production and overhead costs. } \\
\text { Calculation of the reduced prime cost (based } \\
\text { on variable costs only) according to objects or } \\
\text { responsibility centers. } \\
\text { A special scheme for developing the income statement } \\
\text { (marginal approach). } \\
\text { Estimation of stocks of unfinished production and } \\
\text { finished products at reduced prime cost (Nikolaeva, } \\
\text { 1993, p. 36) }\end{array}$ \\
\hline $\begin{array}{l}\text { Absorption } \\
\text { costing }\end{array}$ & $\begin{array}{l}\text { The prime cost of products includes all costs (including } \\
\text { overhead costs), the prime cost of production unit } \\
\text { includes overhead costs }\end{array}$ & $\begin{array}{l}\text { The availability of methods of allocation of overhead } \\
\text { costs suitable for the enterprise activity conditions }\end{array}$ \\
\hline Standard cost & $\begin{array}{l}\text { Cost of resources planning (material, labor, etc.) } \\
\text { according to the cost of resources standards per } \\
\text { production unit. } \\
\text { Separate reflection in the accounting of standard costs } \\
\text { and deviations from them, and not what arose (actual } \\
\text { costs), not actual (fact), but proper (standard), and } \\
\text { separate accounting of deviations in the financial results } \\
\text { of the enterprise }\end{array}$ & $\begin{array}{l}\text { Availability of a system of standards (norms and } \\
\text { regulations) of the cost of resources per unit of } \\
\text { production. } \\
\text { Separate cost accounting according to the norms } \\
\text { (standards) and deviations of actual costs of resources if } \\
\text { compared to the norms (standards) of costs }\end{array}$ \\
\hline $\begin{array}{l}\text { CVP analysis } \\
\text { (breakeven } \\
\text { point analysis) }\end{array}$ & $\begin{array}{l}\text { Since it is based on a comparison of three values - } \\
\text { enterprise costs, sales return and profit gained, its ratio } \\
\text { makes it possible determine the sales return (volume } \\
\text { of sales), which, in the case of known values of fixed } \\
\text { costs of and variable costs of the enterprise per unit of } \\
\text { production, will ensure breakeven activity or planned } \\
\text { financial result }\end{array}$ & $\begin{array}{l}\text { Following the system of assumptions (constant prices } \\
\text { for products of the enterprise, division of costs into } \\
\text { variable and fixed, zero deviations between the actual } \\
\text { values of fixed and variable costs and the planned ones) }\end{array}$ \\
\hline ABC method & $\begin{array}{l}\text { The amount of enterprise costs during a period or } \\
\text { costs for a certain type of product is determined based } \\
\text { on the cost of the implementation of a number of } \\
\text { processes and operations being part of the enterprise } \\
\text { activity }\end{array}$ & $\begin{array}{l}\text { The use of process approach in the enterprise } \\
\text { management (activity as a number of processes and } \\
\text { operations). } \\
\text { Determination of operations according to the types of } \\
\text { activity of the enterprise. } \\
\text { Extension of the existing accounting system }\end{array}$ \\
\hline Kaizen costing & $\begin{array}{l}\text { Constant reduction of costs of the enterprise in all fields } \\
\text { of its activity thanks to the reduction of costs that are } \\
\text { not associated with production in processes, operations } \\
\text { and types of activity (Imai, 1986) }\end{array}$ & $\begin{array}{l}\text { Close cooperation between functional units of the } \\
\text { enterprise to ensure continuous improvement of } \\
\text { processes at the enterprise to reduce costs. } \\
\text { Active engagement of employees of the enterprise in } \\
\text { reducing the cost of processes, operations, and types } \\
\text { of activities of the enterprise requiring major changes } \\
\text { in personnel management, in particular the availability } \\
\text { and constant development of the incentive program for } \\
\text { the enterprise personnel }\end{array}$ \\
\hline Cost killing & $\begin{array}{l}\text { Maximal reduction of costs within the shortest possible } \\
\text { period of time without significant changing in the } \\
\text { enterprise activity and threat to its growth }\end{array}$ & $\begin{array}{l}\text { Availability of complete and accurate information on } \\
\text { the enterprise costs. } \\
\text { Willingness of managerial personnel (owners) of the } \\
\text { enterprise to reduce costs. } \\
\text { Engagement of all employees of the enterprise in the } \\
\text { search of cost reduction reserves }\end{array}$ \\
\hline
\end{tabular}

counting information on the enterprise costs using the chosen cost management method. But it is challenging to introduce at the enterprise the management accounting (which is parallel to the financial accounting in actual fact), along with the undeniable advantages for cost management, it may cause extra costs (even despite of almost complete computerization of management and financial accounting). The increase in costs is a downturn for the economics of enterprises, especially for those that are trying to compete by price. That is why a vast majority of domestic enterprises refuse management accounting despite worsening the information exchange between the cost man- agement functions. Little less than the studied enterprises do not use management accounting and managers of only a few companies believe it is worth introducing (but are not going to use it).

\section{RESULTS}

All activities of the company - dedicated to production and marketing - are accompanied with the occurrence and collection of costs (provision of services and performance of works). Thus, bringing the amount and the structure of the costs in line with the conditions of production and sale 
are being implemented in all functions of the enterprise (production, maintenance, reproduction and management) (Voronkova, 2007, pp. 85-87) and within all functional subsystems of the enterprise management:

- in the production subsystem - improving organizational and technical level of production;

- in the marketing (or market) subsystem choosing more cost-conscious ways of promotion in the market and reducing transaction costs of the enterprise, accordingly;

- in personnel subsystem - more effective motivation of employees of the enterprise; in the innovation subsystem - from the switch to new (for instance, energy-saving) technologies, types of products or structural materials.

The diversity and multiplicity of the enterprise activities on the production and marketing of products and, accordingly, the diversity of costs cause the formation of costs for various objects - types of products (works, services), business processes, enterprise functions or functional management enterprise subsystems, in its turn leading to the occurrence of various structures of costs. That is why it is so important that the costs of the enterprise are planned, accounted, controlled, and analyzed based on the chosen objects.

Table 2. Advantages and limitations of the methods of operational enterprise cost management

\begin{tabular}{|c|c|c|}
\hline Method & Advantages & Limitations \\
\hline Direct costing & $\begin{array}{l}\text { The relevant data may be received from regular } \\
\text { financial statements without additional accounting } \\
\text { procedures. } \\
\text { Profit for the period does not depend on constant } \\
\text { overhead costs when changing residue stock. } \\
\text { The distribution of overhead costs is simplified, } \\
\text { there emerges the possibility of determination of the } \\
\text { contribution of each type of product in the formation of } \\
\text { the enterprise profit. } \\
\text { Makes it possible to determine the price for new } \\
\text { products and choose between own production or the } \\
\text { purchase of goods }\end{array}$ & $\begin{array}{l}\text { Many types of costs are hardly categorized as variable } \\
\text { or fixed. } \\
\text { Lack of attention to fixed costs. } \\
\text { A distortion of the financial result due to underpricing } \\
\text { Or overpricing of the finished products. } \\
\text { Creation of the illusion of profitability of technologically } \\
\text { complex, solid -investment projects }\end{array}$ \\
\hline $\begin{array}{l}\text { Absorption } \\
\text { costing }\end{array}$ & $\begin{array}{l}\text { Lack of division of the enterprise costs into fixed and } \\
\text { variable. } \\
\text { enterprise. } \\
\text { The reflection of the coverage by income from the sale } \\
\text { of products of each type or type of activity of both } \\
\text { direct variable costs and fixed overhead costs. } \\
\text { Increased relevance of choosing or refusing an } \\
\text { additional order }\end{array}$ & $\begin{array}{l}\text { Retrospectively and conditionality of allocation of } \\
\text { overhead costs. } \\
\text { Determination of the actual prime cost of the } \\
\text { production unit only at the end of the period. } \\
\text { Conditional nature of the allocation of overhead costs. } \\
\text { Inclusion in the prime cost of production costs that } \\
\text { are not directly associate with production, added } \\
\text { complexity of accounting and settlement procedures, } \\
\text { lack of attention to the nature of the behavior of costs, } \\
\text { depending on the volume of products being produced }\end{array}$ \\
\hline Standard cost & $\begin{array}{l}\text { Formation of the informational base required for the } \\
\text { analysis and control of costs, visibility of deviations } \\
\text { from the plan in the course of costs formation. } \\
\text { Minimization of accounting work associated with the } \\
\text { calculation of prime cost, timely provision of managers } \\
\text { with information on the expected production costs }\end{array}$ & $\begin{array}{l}\text { May be effectively used for periodically wheeling costs. } \\
\text { The effectiveness depends on the content and quality } \\
\text { of the regulatory structure. } \\
\text { The impossibility of determination of norms for certain } \\
\text { types of costs }\end{array}$ \\
\hline $\begin{array}{l}\text { CVP analysis } \\
\text { (breakeven } \\
\text { point analysis) }\end{array}$ & $\begin{array}{l}\text { Possibility of determination of the volumes of sales } \\
\text { providing breakeven production or the planned } \\
\text { financial result. } \\
\text { Simplicity, visibility, and operational efficiency of the } \\
\text { method }\end{array}$ & $\begin{array}{l}\text { The need for major changes in accounting and } \\
\text { improvement of information support systems thus } \\
\text { increasing the management costs }\end{array}$ \\
\hline $\mathrm{ABC}$ method & $\begin{array}{l}\text { Increased relevance for attributing overheads to a } \\
\text { certain product, more precise prime cost calculation. } \\
\text { Provision of relations between the information received } \\
\text { and the process of cost formation }\end{array}$ & $\begin{array}{l}\text { Division of the enterprise costs into variable costs that } \\
\text { linearly depend on the volume of products and fixed } \\
\text { costs that do not depend on it, that is really hard to } \\
\text { implement. } \\
\text { Any change of the factors of the model (variable and } \\
\text { fixed costs, volume of sales, and price) can significantly } \\
\text { change the final result. } \\
\text { It is based on the supposition that labor productivity, } \\
\text { being a direct determinant of variable costs, does not } \\
\text { depend on the scale and does not change with time, } \\
\text { and there are no structural changes in the quality } \\
\text { marking the change in the enterprise system }\end{array}$ \\
\hline Kaizen costing & $\begin{array}{l}\text { Provide constant costs reduction and its keeping at the } \\
\text { set level }\end{array}$ & $\begin{array}{l}\text { Engagement of personnel if an incentive program is } \\
\text { introduced }\end{array}$ \\
\hline Cost killing & Fast reduction of enterprise costs & $\begin{array}{l}\text { Severity of the method. } \\
\text { To be used in a consistent manner }\end{array}$ \\
\hline
\end{tabular}


But to be able to predetermine the formation of costs of the enterprise that has various localizations (according to the type of product, business processes, enterprise functions, functional subsystems of enterprise management, responsibility centers, etc.), it is necessary to operationalize the concepts of the chosen method to be used in the functional cost's management methods.

The methods of functional cost management are intended to be used for interrelated calculations using cost data, prepared in a certain format and cost indicators based on the cost management functions. The consistency of functional cost management methods (at least by the content of the calculations and their results) is crucial for effective use of cost management methods at the enterprise. The consistency of functional planning and cost accounting methods means that in the course of their usage, it is possible to receive the same cost indicators, however, of course, for the planning and reporting period. Failure to bring cost management functional methods into accordance may cause a managerial conflict that, in its turn, may lead to the absence of actual values of some planning costs indicators due to the inability of the accounting to provide information required for their calculation.

Today, there are grounds for believing that the consistency of functional planning methods and cost accounting is very weak. Thus, for instance, based on the functional enterprise management subsystems, it is possible to determine planning costs, but the current system of enterprise accounting restricts the ability to collect actual data on functional subsystems costs. Since only the data on costs by types and objects are available, it is quite difficult to control the formation of costs and virtually impossible to analyze them by functional subsystems. Other objects of costs also have a weak consistency of functional cost planning and accounting methods.

The concepts of the cost management methods are operationalized by determination of a systematic set of operations, techniques and procedures being used on a single methodical basis during the period set for each of the functions of cost management to calculate the planning and actual costs of the enterprise following the approved assumptions, conditions, and requirements. In other words, the concepts of the enterprise cost management method are to be used in functional cost management methods (first of all, in planning and accounting methods) in the form of determined operations, techniques, procedures, and algorithms being applied to generate data on the formation, localization and structure of costs. That is why the enterprise cost management methods require reduction making it possible for each of the functions of cost management to simplify the method by determination of a specific range of operations, techniques, procedures and algorithms - as well as the form of their performance - of the information used within the basic functions.

The reduction of the enterprise cost management method makes it possible to narrow the key idea of the cost management method down to a set of actions, operations and calculations being made according to the algorithms available by the experts of the enterprise who implement a certain cost management function. The reduction of the enterprise cost management method makes it possible for the experts of the enterprise engaged in planning, accounting or analytics, to be clear about their role, while using the cost management method chosen by the enterprise makes this method more open and clear thanks to functional management methods that are developed for the implementation of each of the functions of enterprise cost management, such as planning, accounting, and analysis of costs.

A method of planning is considered a sequence of calculations of planning cost indicators according to the algorithm developed. These indicators reflect the amount and the relation of costs with other indicators of the activities of the enterprise in the future. Following this sequence of calculations along with using a variety of data from all functional enterprise management subsystems makes it possible to receive the value of planning cost indicators. The planning cost indicators of the enterprise are actually a form of presentation of the results of the planning cost behavior reflecting the nature of the response of costs to known or planned changes in the enterprise during the planning period, meaning data on the formation of costs by their types, localization, and mediums. 
Routine methods of cost planning at the enterprise are given in Table 3.

Technologies of the use of cost planning methods are common, widely covered in the scientific literature, and practically applied in cost management at the enterprise. In practice, enterprises are more likely to use several methods of costs planning. Such common use makes it possible to calculate the cost of necessary resources, to calculate the prime cost of production and marketing of each product and its profitability (being the criterion of the minimum price), to determine the total amount of the costs for production of the planned volumes of products and their structure by place of origin, types, and mediums.

The methods of enterprise costs planning practically used in cost management make it possible to operationalize the concepts of almost all cost management methods given in Tables 1-2, that is, to calculate the planning cost indicators of the enterprise. Probably, the ABC method (ActivityBased Costing) may be considered an exception. The use of this method requires a substantially different approach to both the enterprise costs and the object in the management of them.

Some time, the ABC method has been rapidly developed in the theory of costs (for instance, Drury, 1990). The ABC method is based on the process approach to the activity of the enterprise. According to this method, the activity of the enterprise is considered a set of business processes (or workflow processes), and the process becomes the object of control be (Daft, 2010, p. 448). However, the practical use of the Activity-Based Costing remained uncommon in operational cost management (at least in Ukraine), as long as the process approach to enterprise management, which seemed attractive in theory, turned out to be too complicated to put into practice. It has a lot of advantages that are good in theory, but ineffective in practice. That is why the current methods of the enterprise cost planning restrict the ability to implement this method of cost management. In the same way, they restrict the ability to implement the ABC method (Activity-Based Costing) and methods of enterprise costs accounting, since the process is not an object of accounting according to the current standards of financial reporting (both national and international).

CVP analysis or the breakeven point analysis of activity of the enterprise give grounds to recognize, first of all, by the method of analysis, making it possible to combine such aspects of the activity of the enterprise as costs, sales return and profit of the enterprise, and to consider their interinfluence. There is relevant information for the use of CVP analysis in costs planning and accounting at the enterprises.

To make the (Sl'ozko, 2013) interpretation of the cost accounting method clear, in general, this method is a set of techniques of a sequence of fixation (the facts of business operations), registration and recording (based on the primary documents)

Table 3. The most common methods of costs planning at the enterprise

\begin{tabular}{|c|c|}
\hline Method & Nature of the method \\
\hline Normative method & $\begin{array}{l}\text { The amount of costs for the production and marketing of products (works, services) is } \\
\text { calculated based on norms and regulations of the resources cost }\end{array}$ \\
\hline $\begin{array}{l}\text { Technical and economic calculations } \\
\text { method (or calculation and } \\
\text { constructive method) }\end{array}$ & $\begin{array}{l}\text { The amount of costs is determined considering the influence of technical and economic } \\
\text { factors upon the costs of the enterprise in the planned year compared with the previous } \\
\text { one }\end{array}$ \\
\hline Budgetary method & $\begin{array}{l}\text { The estimate of costs is divided into separate complex objects of cost for the whole } \\
\text { volume of production (or on a certain object or project) }\end{array}$ \\
\hline Method of calculations & $\begin{array}{l}\text { The amount of costs for the production and marketing of products is determined to plan } \\
\text { and accounting unit of production (works, services) }\end{array}$ \\
\hline $\begin{array}{l}\text { Functional cost analysis (for variable } \\
\text { costs) }\end{array}$ & There have been determined the best quality - cost ratio of the product \\
\hline Budgeting & $\begin{array}{l}\text { Planning of the future operations of the enterprise (separate units and types of activity) } \\
\text { and preparing its results in the form of budgets system }\end{array}$ \\
\hline $\begin{array}{l}\text { Methods of extrapolation } \\
\text { (determination of averages, } \\
\text { extrapolation, exponential smoothing) } \\
\text { (for fixed costs) }\end{array}$ & $\begin{array}{l}\text { Planning cost indicators are calculated based on their actual values for the previous } \\
\text { period, considering the decrease (increase) thanks to the influence of the past processes } \\
\text { and phenomena upon future (reasoning of the planned indicators values 'based on } \\
\text { achieved') }\end{array}$ \\
\hline Matrix method & $\begin{array}{l}\text { Creation of the process of formation of the enterprise costs by divisions and } \\
\text { technological process operations (performance of works, provision of services) }\end{array}$ \\
\hline
\end{tabular}


of the data on costs in the accounting information medium. This sequence is made according to the international financial reporting standards (that is, if the incurred costs satisfy the criteria for their recognition in the accounting). The somehow formatted data on the enterprise costs - being used for the calculation of the actual values of the enterprise cost indicators - are the result of the use of cost accounting method. And we are talking about calculation of the actual values of those enterprise cost indicators that are prescribed by the corresponding plan.

Within a set of techniques and operations for fixation and recording of the costs data in the accounting information medium, such methods of enterprise cost management as direct costing and standard costing are already widely accepted. Direct costing is actually the basis for cost accounting organization pursuant to the international financial reporting standards. Modern scientific literature in great detail covers the background for their occurrence, the nature, advantages, restrictions and practical use in cost accounting (Drury, 1990; Drury, 2007; Zusmanovich, Kerimov, \& Rummel, 1949; Elliott, 2014; Apak, Erol, Elagöz, \& Atmaca, 2012).

Thanks to operationalization of the concepts of direct costing and standard costing in functional methods of cost planning and accounting at the enterprise, these cost management methods are extensively used at Ukrainian enterprises, making it possible to implement the functions of costs analysis and control and create the foundations for the cost management system at the enterprise, based on the use of direct costing and standard costing.

However, nowadays the possibilities of direct costing and standard costing in the operational cost management at the enterprises with any kind of activity are becoming exhausted. These methods are of little efficiency for the target level of costs of the enterprise, being crucial for enterprises in any country with the desire to win the competitive struggle, especially in international markets, by the products price (or services).

Broadly speaking, standard costing and direct costing are more like to reflect the costs structure, since the total amount of costs, while using one of these management methods, remains unchanged and the procedures of managerial influence are poorly implemented. So, the practical use of standard costing and direct costing demonstrated that these methods are more closely associated with the methods of structuring of the enterprise costs (referred to in Emelyanov (2013)) thus reducing their managerial value. Because the structuring of costs itself fails to provide the possibility of managerial influence, but only changes the view on the allocation of the total amount of costs according to the chosen criteria.

Today, the methods of enterprise expenses management - designed to reduce the price and improve the price competitiveness of the products of the company - are being brought up to date. With all the importance of non-price competition, price competition is firmly holding its positions.

Today, the use of such cost management methods as absorption costing, kaizen costing, and cost killing may ensure the price competitiveness of the enterprise with any kind of activity.

The use of absorption costing makes it possible to determine the full prime cost of sold products and, accordingly, the calculation unit, as long as indirect (overhead) costs are distributed by type of product based on the allocation base chosen for the planning and accounting policy of the enterprise. One of the advantages of absorption costing is that it is possible to manage costs of the enterprises with both a specific type of production, where the products are made according to individual orders (Job-Order Costing), and continuous production, based on the standardized stages of technological processing, in which it is quite difficult to allocate the production of specific products (Process Costing) (Zusmanovich, 2005).

Absorption costing is appropriate under the conditions of price competition, since its use helps managers of enterprises receive data on the full prime cost of a unit of production and, accordingly, to determine the price for products (work, services) of the enterprise. The results of comparison of the planning price of products (works, services) of the enterprise, determined based on the full prime cost of a unit of production (with different ways of 
allocation of indirect (overhead) costs of the enterprise by the types of product), with prices for the same or similar products, already existing in the market, are fundamental for making a decision on the practicability of production of products (performance of works or provision of services), entering the market, or recognition price in competitiveness of the products of the enterprise and, accordingly, refusal to produce such products.

The methods of cost planning at the enterprise make it possible to operationalize the concepts of absorption costing, despite possible inaccuracies in the allocation of indirect (overhead) costs of the enterprise by the types of product. Eventually, the accuracy of allocation of such costs is not a decisive requirement for the use of absorption costing, particularly when the price is a major competitive advantage of the enterprise. Thanks to the great variety of available allocation bases of indirect (overhead) costs of the enterprise by the types of production, it is possible to make allocation is such a way that there are no unprofitable products, works or services of the enterprise (if there are others, except for purely economic reasons, to produce or perform them).

Kaizen costing, along with the products quality improvement and better organization (labor, production, and management), provides constant, continuous and all-around reduction of the enterprise costs thanks to brand new technical or organizational innovations and by the gradual liquidation of unproductive costs (Imai, 1986).

Cost killing is a short-term effect method being appropriate in anti-crisis management. It is impossible to continuously reduce costs in constant conditions of activity of the enterprise. Otherwise, such a short-term win of the enterprise may erase prospects for its growth, which, among other things, is ensured by the current costs that will bring income in the future. That is why the use of cost killing requires thorough substantiation of the reduction of certain types of costs, since such an unsubstantiated minimization may, in some circumstances, do harm rather than benefit.

In the methods of the enterprise costs planning it is quite possible to operationalize: absorption costing by the development of algorithms for calculating the full prime cost of a unit of production;

- kaizen costing and cost killing by the development of algorithms for calculating the volume of the potential reduction of enterprise costs within a given period of time thanks to organizational and technical changes.

But it makes no sense to calculate cost indicators according to the developed algorithms if there are no cost accounting methods that make it possible to fix and record in the accounting information mediums the data on the full prime cost per unit of production or the reduction of the enterprise costs within a given period of time thanks to organizational and technical changes.

The forms of accounting and the accounting policies approved at the enterprise may promote or refuse the use of specific method of cost management at the enterprise. That is why it is critical to know whether accounting organization and accounting policies of the enterprise allow to use the cost management method chosen by its managers, what type of changes are required, and to what extent the accounting experts are ready to make such changes. Moreover, such changes should be made according to the applicable international financial reporting standards. If the accounting experts see no need to make changes in the accounting organization and accounting policies of the enterprise, it is necessary to choose other methods of enterprise costs management.

The requirements for costs accounting at the enterprise, determined by the authors, while using absorption costing, kaizen costing, and cost killing in the operational enterprise costs management are given in Table 4.

These requirements for costs accounting at the enterprise while using absorption costing, kaizen costing, and cost killing in the operational enterprise costs management make it possible to determine components of the accounting policy at the enterprise, being fundamental for fixation and registration of the costs data in the accounting information mediums (Table 5). 
Table 4. Requirements for the costs accounting while using absorption costing, kaizen costing, and cost killing in operational enterprise costs management

\begin{tabular}{l|l}
\hline \multicolumn{1}{c|}{ Method } & \multicolumn{1}{c}{ Requirements for the method } \\
\hline Absorption costing & $\begin{array}{l}\text { Presence in the accounting policy of the enterprise of the costs allocation bases, being consistent with } \\
\text { the appropriate base in costs planning. } \\
\text { Division of costs into direct and indirect. } \\
\text { Accounting of finished stock at full prime cost }\end{array}$ \\
\hdashline Kaizen costing & $\begin{array}{l}\text { Accounting of all, even small changes in enterprise costs with localization of changes } \\
\text { Cost killing }\end{array}$ \\
\hline
\end{tabular}

Table 5. Components of the accounting policy at the enterprise required for the use of absorption costing, kaizen costing, and cost killing in operational enterprise costs management

\begin{tabular}{l|l}
\hline Method & \multicolumn{1}{c}{ Components of the accounting policy } \\
\hline Absorption costing & $\begin{array}{l}\text { Cost drivers for each type of indirect (overhead) costs. } \\
\text { The procedure of calculation of the value of unfinished production at the end of the period by full prime } \\
\text { cost, considering the allocated overhead costs. } \\
\text { The order of allocation of shared and mutual indirect (overhead) costs of the enterprise }\end{array}$ \\
$\begin{array}{l}\text { Working plan of accounts with localization of each type of enterprise costs. } \\
\text { Separate sub count in the working plan of accounting of costs at the enterprise within norms and } \\
\text { beyond them (norms, if compared to the standard costing, are not constants, but are determined by the } \\
\text { value of the indicators of the previous period) } \\
\text { Criteria for operations (and costs occurring within operations) for critical operations and operations that } \\
\text { can be ignored. } \\
\text { Separate transit accounts for cost accumulation that may be and may not be ignored according to } \\
\text { specific criteria. }\end{array}$ \\
\hline
\end{tabular}

According to the components, given in Table 5, of accounting policy for specified methods of operational cost management, the authors provided specific changes in the organization of enterprise accounting that should be introduced in order to use methods of operational cost management (Table 6).

There is no unified approved plan of accounts according to the International Financial Reporting Standards (IFRS). An enterprise with any type of activity is free to develop an account plan based on its needs, subject to the IFRS. To implement separate accounts to use the analyzed accounting methods there have been used the names of such accounts rather than unnumbered account codes (as would be appropriate while using the national accounting provisions (standards) in Ukraine).

The offered changes of the cost accounting for the use of absorption costing, kaizen costing, and cost killing in operational enterprise costs management coincide with the approved correspondence of accounts, principles and conceptual basis of accounting, prescribed by the IFRS and make it possible to record and collect additional accounting

Table 6. Changes in the organization of enterprise accounting required for the use of absorption costing, kaizen costing, and cost killing in operational enterprise costs management

\begin{tabular}{|c|c|}
\hline Method & Changes in the organization of accounting \\
\hline Absorption costing & $\begin{array}{l}\text { The traditional absorption costing procedure of allocation of the indirect (overhead) costs for accounts, } \\
\text { associated with products, along with the traditional way of reflection of certain types of costs on the } \\
\text { cost accounts by some objects of cost }\end{array}$ \\
\hline Kaizen costing & $\begin{array}{l}\text { Implementation of sub count of each type of costs with sub-accounts in order to make multidimensional } \\
\text { accounting to reflect incurred costs within norms and beyond them. For instance, implementation he } \\
\text { transits accounts for reasonable and unproductive (according to the specific criteria) costs makes it } \\
\text { possible to separately accumulate reasonable and unproductive costs (within analytical accounting), } \\
\text { while providing the integrity of the structure of each account and following the procedure of cost } \\
\text { apportionment. The total amount of costs on their accounts does not change, but the introduction of } \\
\text { the offered transit accounts will make it possible to track excessive costs compared to the previous } \\
\text { period }\end{array}$ \\
\hline Cost killing & $\begin{array}{l}\text { Introduction of transit accounts in order to accumulate costs data for a period of time that may be and } \\
\text { mat not be ignored. } \\
\text { Implementation of transit accounts 'critical operations costs' and 'non-critical operations costs' } \\
\text { (according to the accounting policy criteria). The implementation of the correspondence of such transit } \\
\text { accounts is similar to other cost accounts prior to the accumulation of cost apportionment information, } \\
\text { will make it possible to keep the structure of costs on cost accounts by apportionment with the } \\
\text { simultaneous collection of information on the need for such costs. }\end{array}$ \\
\hline
\end{tabular}


Table 7. Use of methods of operational cost management at the enterprises of Ukraine

\begin{tabular}{|c|c|c|c|c|}
\hline \multirow{2}{*}{$\begin{array}{l}\text { Method of operative cost } \\
\text { management }\end{array}$} & \multicolumn{2}{|c|}{ Enterprises that use a method } & \multicolumn{2}{|c|}{$\begin{array}{l}\text { Enterprises that have experts } \\
\text { for a specific method }\end{array}$} \\
\hline & $\begin{array}{c}\text { Total } \\
\text { number }\end{array}$ & $\begin{array}{l}\% \text { of total number } \\
\text { of enterprises }\end{array}$ & Total number & $\begin{array}{c}\% \text { of total amount } \\
\text { of studied enterprises }\end{array}$ \\
\hline Direct costing & 23 & 82.1 & 28 & 100.0 \\
\hline Standard costing & 18 & 64.3 & 27 & 96.4 \\
\hline Absorption costing & 5 & 17.8 & 23 & 82.1 \\
\hline CVP analysis & 12 & 42.8 & 13 & 46.4 \\
\hline$A B C$ method & 1 & 3.6 & 8 & 28.6 \\
\hline Kaizen costing & 0 & 0.0 & 3 & 10.7 \\
\hline Cost killing & 2 & 7.2 & 4 & 14.3 \\
\hline
\end{tabular}

information on the costs of the enterprise depending on the nature of each of these methods:

- some sub counts, while using kaizen costing, will contain data on the received results on the reduction of costs and improvement of the quality of operations at the enterprise;

- the turnover at some offered transit cost accounts for the cost killing will reflect the amount of costs to be reduced in the future and the amount of the enterprise's minimum costs required for operation.

The methods of operational cost management will remain in theory, unless provided to the employees of the enterprises. So, in order to discover the awareness of economists-practitioners (on costs planning and accounting) of the enterprises, 28 enterprises were polled in Poltava, Poltava region, Kharkiv, Kharkiv region, Severodonetsk region, and Luhansk regions. The respondents were middle-management experts of financial and planning services of enterprises (managers of economic services, planning and financial departments, accounting department). The results of the polling are given in Table 7.

Thus, in practice, cost management tends to use the most common and traditional methods, such as direct costing, absorption costing, and standard costing. Some of the studied enterprises use several methods of cost management. Thus, out of 23 enterprises that use direct costing, 16 enterprises were additionally using a standard costing, and out of 5 enterprises that used absorption costing, 2 enterprises were additionally using a standard costing.
The breakeven point analysis is quite widely used if compared to other methods. Other analyzed methods of operational cost management at domestic enterprises are not being used. Except for the failure to use methods that have proved their effectiveness and performance in operational cost management, unawareness of domestic experts of such methods is yet another problem.

The results of polling of the experts of the enterprises being studied on the methods of operational cost management may be used for the formation of certain evaluative judgments on the quality of cost management at domestic enterprises.

\section{DISCUSSION}

A compulsory condition for the effective use of cost management methods at the enterprise is the consistency of functional methods, and, first of all, the methods of cost planning and accounting. There is no such consistency yet: functional cost planning methods make it possible to determine their volume depending on different objects (types of product, functional subsystems, or business processes), and functional cost accounting methods make it possible to receive data only by types and objects of cost.

The consistency criterion of functional cost management methods is the identity of the structure of the data on the planning and actual costs of the enterprise making it possible to calculate the planning and actual cost indications for the chosen objects that can be compared and, according to the results of comparison, analyze the costs of the enterprise. In other words, methods of cost planning 
and accounting are deemed consistent if their use is resulted in equal, in terms of amount and structure, planning and actual costs of the enterprise.

If the functional cost management methods are inconsistent, there occurs a managerial collision that complicates the analysis of the cost amount and structure and the decision - making on the setting of the product price: there are no relevant costs data in their records or their obtaining takes too much time causing irrelevance of these data. Enterprises refuse to introduce the accounting management to eliminate the specified managerial collision since it may require some organizational efforts and lead to management costs increase.

The consistency of functional cost management methods at the enterprise is ensured by the enterprise management costs reduction, making it possible to narrow the key idea of the method of cost management down to a number of actions, operations, and calculations being made within the cost planning and accounting or, in other words, to operationalize the concepts of the method.

The reduction is particularly topical for those methods of enterprise costs management, the use of which help predetermine the reduction of costs, thus improving price competitiveness of the enterprise (absorption costing, kaizen costing, and cost killing).

In order to ensure the consistency of functional cost management methods, the article has determined changes in cost accounting for the use of absorption costing, kaizen costing, and cost killing in operational enterprise cost management, ensuring the consistency of planning and actual data on the costs of the enterprise and their analysis.
The offered changes in cost accounting for the use of absorption costing in the operational enterprise costs management makes it possible to somehow ensure the consistency of functional management methods, but fail to resolve the issue of consistency in full. Today, the issue of determination of the costs for new, modern types of management activities, for instance, to ensure the economic security of the enterprise (for security-providing activities), its competitiveness, development, etc., is very topical for enterprise management. But the existing cost accounting methods restrict the ability to receive relevant data. They can only be received from primary accounting, which is time consuming.

The provisions above provide grounds for believing that the incomplete solution of the issue of ensuring the consistency of methods of cost planning and accounting at the enterprise lowers the cost management quality, since the possibilities for analysis of the behavior of costs, their structure, sources of origin, effectiveness and efficiency are limited, planning of costs for management objects and types of management activity lose its significance due to the absence of possibility to receive relevant data on cost accounting. Further solution of the issue of ensuring the consistency of methods of costs planning and accounting at the enterprise is seen in the strengthening of the focus of the enterprise accounting to satisfy the needs of internal users of the cost accounting information. And against this background it is pointless to refer only to the possibilities of management accounting, since the accounting forms and the accounting policies used at the enterprise require changes, which will make it possible to fix and record, in the accounting information mediums, the data necessary while using the most effective methods in enterprise costs management.

\section{REFERENCES}

1. Apak, S., Erol, M., Elagöz, İ., \& Atmaca, M. (2012). The Use of Contemporary Developments in Cost Accounting in Strategic Cost Management. Procedia - Social and Behavioral Sciences, 41, 528-534. https://doi.org/10.1016/j.sbspro.2012.04.065

2. Backhouse, R. (2004). The ordinary business of life: a history of economics from the ancient world to the twenty- first century. Princeton: Princeton University Press.

3. Backhouse, R. E. (2008). Marginal revolution. In S. N. Durlauf \& L. E. Blume (Eds.), The new Palgrave dictionary of economics (pp. 292-294). London: Palgrave Macmillan.

4. Clark, J. M. (1923). Studies in the Economics Overhead Costs. Chicago: University of Chicago Press.
5. Commons, J. R. (1959). Institutional Economics, Its place in the political economy. Madison: The University of Wisconsin Press. Retrieved from https://babel.hathitrust.org/cgi/pt?i $\mathrm{d}=$ mdp.49015000887415;view=1up ;seq $=15$

6. Coase, R. H. (1937). The nature of the firm. Economica. New Series, 4(16), 386-405. Retrieved from https://onlinelibrary.wiley.com/ 
doi/full/10.1111/j.1468-0335.1937. tb00002.x

7. Daft, R. L. (2010). Management (9th ed.). Boston: Cengage Learning.

8. Drury, C. (1990). Costing: an Introduction (2nd ed.). London: Chapman \& Hall.

9. Drury, C. (2007). Management \& Cost Accounting (7th rev. ed.) Boston: Cengage Learning.

10. Elliott, G. (2004). The Seven Principles of Effective Cost Management. Retrieved from https://www.naturalproductsinsider. com/articles/2004/11/the-sevenprinciples-of-effective-cost-management.aspx

11. Emelyanov, A., Kurylo, O., \& Vysotskij, A. (2013). Structuring expenses of industrial enterprises in the evaluation process of its production and sales potential. Ekontech mod. An international quarterly journal, 2(4), 11-16.

12. Fiorito, L. (2018). John M. Clark and Frank H. Knight on the AddingUp Theorem, Overhead Costs, and More. Research in the History of Economic Thought and Methodology, 36A, 159-179. Retrieved from https://www.emeraldinsight com/doi/pdfplus/10.1108/S074341542018000036A010

13. Frank, W. G. (1990). Back to the future: A retrospective view of J. Maurice Clark's Studies in The Economics of Overhead Costs. Journal of Management Accounting Research, 2, 155-166. Retrieved from http://maaw.info/ArticleSummaries/ ArtSumFrank90.htm

14. Garg, A., Ghosh, D., \& Halper, H. (2004). Best practices in management accounting. Journal of Cost Management, 18(2), 21-25. Retrieved from https://www.palgrave. com/gp/book/9780230358362

15. Georgas, P. G., \& Vallance, G. V. (1986). Cost management. Project Management Journal, 17(3), 47-54.

16. Hansen, D. R., Mowen, M. M, \& Liming, G. (2009). Cost Man- agement: Accounting and Control (6th ed.). Boston: Cengage Learning.

17. Horngren, C. T., Foster, G., Datar, S. M., Rajan, M. V., \& Ittner, C. M. (2008) Cost Accounting: A Managerial Emphasis (13th ed.). London: Pearson.

18. Imai, M. (1986). Kaizen The key to Japan's Competitive Success. NewYork: McGraw-Hill Inc.

19. Kerimov, V. E. (2001). Организация управленческого учета по системе "Директкостинг» [Organizatsiya upravlencheskogo ucheta po sisteme "Direkt-kosting"]. Retrieved from http://www.management.com.ua/ finance/fin040.html

20. Kozachenko, H. V., Pogorelov, Yu. S., \& Makukhin, H. A. (2007). Управління затратами підприємства [Upravlinnia zatratamy pidpryiemstva]. Kyiv: Libra.

21. Marx, K. D. McLellan (Ed.) (2008). Capital: An Abridged Edition. Oxford: Oxford Paperbacks.

22. North, D. C., \& Wallis, J. J. (1994). Integrating institutional change and technical change in economic history; a transaction cost approach. Journal of Institutional and Theoretical Economics, 150(4), 610-634. Retrieved from http://econweb. umd.edu/ wallis/MyPapers/N\&W_ JITE_1994.pdf

23. O'Sullivan, A., \& Sheffrin, S. M. (2003). Economics: Principles in Action. Upper Saddle River: Pearson Prentice Hall.

24. Ricardo, D. (1941). Сочинения, Том 1: Начало политической экономии и налогообложения [Sochineniya, Vol 1: Nachalo politicheskoy ekonomii i nalogooblozheniya]. Moskva: Gospolitizdat.

25. Rummel, K. (1949). Einheitliche Kostenrechnung auf der Grundlage einer vorausgesetzten Proportionalität der Kosten zu betrieblichen Gröben. Dusseldorf.
26. Sahaf, M. A. (2013). Management Accounting. Principles and Practice (3rd ed.). New Delhi: Vikas Publishing House PVT LTD.

27. Slozko, Т. (2013). Методи обліку витрат чи методи управління витратами: проблема дефініцій [Metody obliku vytrat chy metody upravlinnia vytratamy: problema definitsii]. Bukhhalterskyi oblik $i$ audyt, 4, 16-21.

28. Smith, A. (2015). The Wealth of Nations: A Translation into Modern English (523 p.). Manchester: Industrial Systems Research.

29. Tichacek, R. L. (2006). Effective Cost Management. Back to Basics. Cost Engineering, 48(3), 27-33. Retrieved from http://www.icoste.org/ aace $2005 \% 20$ papers/csc11.pdf

30. Upchurch, A. (1998). Management Accounting: Principles \& Practice, Upper Saddle River (New Jersey). Financial Times Press.

31. Voronkova, A. E., Kozachenko, A. V., \& Ramazanov, S. K. (2007). Современные технологии управления промышленным предприятием [Sovremennye tekhnologii upravleniya promyshlennym predpriyatiem]. Kyiv: Libra.

32. Wideman, R. M. (1983). Cost Control of Capital Projects and the Project Cost Management System Requirement. Vancouver, B.C.: AEW Services.

33. Wieser, F. (1889). Natural Value. Retrieved from http://praxeology. net/FW-NV.htm

34. Williamson, O. E. (1981). The Economics of organization: the transaction cost approach. American Journal of Sociology, 87(3), 548-577. Retrieved from https://www.jstor. org/stable/2778934?origin=JSTORpdf\&seq=1\#page_scan_tab_contents

35. Zusmanovich, K. (n.d). Absorption Costing. Retrieved from http:// www.gaap.ru/biblio/mngacc/ foreign/001.htm 